\title{
Penguatan Tata Kelola Transparansi Informasi Publik, Akuntabilitas, dan Efisiensi Keuangan di Universitas Demi Mewujudkan Good University Government
}

\author{
Mohammad Khusnu Milad (1), Achmad Teguh Wibowo(2), Yunan Athoillah(3) \\ Fakultas Ekonomi dan Bisnis Islam UIN Sunan Ampel(1) \\ Fakultas Sains dan Teknologi UIN Sunan Ampel(2) \\ Fakultas Ekonomi dan Bisnis Islam UIN Sunan Ampel(3)
}

Jl. A Yani 117, Surabaya, Indonesia | m.milad @uinsby.ac.id(1), atw@uinsby.ac.id(2), yunan.athoillah@uinsby.ac.id

\begin{abstract}
Abstrak : Keuangan merupakan salah satu bagian dari kebutuhan dasar dalam pelaksanaan fungsi dari suatu lembaga tanpa terkecuali lembaga pendidikan yang dalam hal ini adalah Universitas. Dalam manajemen keuangan, Universitas biasanya memiliki bidang khusus dalam pengelolaan dimana biasanya ada bidang keuangan baik di Rektorat maupun di Fakultas masing masing dalam Universitas. Selain itu dalam sistem koordinasi internal jabatan juga terdapat keberadaan Wakil Rektor maupun Wakil Dekan di bidang keuangan. Secara garis besar pengelolaan kampus melalui sistem informasi dalam hal bidang keuangan sagat diperlukan untuk mewujudkan Good University Government. Dalam pelaksanaannya setiap universitas memiliki mekanisme mekanisme tersendiri terkait dengan manajemen keuangannya. Maka dari itu perlu diterapkan Akuntabilitas, Transparansi dan Efisiensi keuangan di universitas demi menciptakan konsep Good Governance dalam lingkup kampus atau disebut Good University Government. Good University Government merupakan salah satu upaya untuk menata universitas yang baik dalam mencerminkan kesuksesan universitas agar menghasilkan lulusan-lulusan yang berkualitas dan siap bersaing dalam pada persaingan dunia global. Oleh karena itu, sangat dibutuhkan sebuah kerja keras dan tingkat kedisiplinan tinggi dalam mendidik, serta mengajarkan nilai-nilai budaya masyarakat global. Dalam menciptakan tata kelola universitas yang baik dan bersih, sebuah universitas atau perguruan tinggi tentunya harus memiliki tenaga pendidik yang mempunyai kualifikasi dan kompetensi unggul, serta memiliki efisiensi dan produktivitas pembelajaran yang tinggi. Selain itu, universitas juga diharuskan mampu menggali dana dengan bekerjasama dengan mitra bisnis dalam mengembangkan unit-unit bisnisnya.
\end{abstract}

Keywords: Keuangan, Akunabilitas, Transparansi, Efisiensi, Good Uinversity Government. 


\section{Pendahuluan}

Pengelolaan sistem keuangan Universitas adalah keseluruhan kegiatan yang meliputi perencanaan, pelaporan, pelaksanaan, pertanggungjawaban serta pengawasan sistem keuangan yang ada pada universitas dimana aspek ini sangat penting dalam pengelolaan sistem keuangan universittas. Pengelolaan sistem keuangan pada universitas uinsa menggunakan sistem perbulan hingga tahunan dan berorientasi pada mahasiswa . Dalam hal ini pelayanan mahasiswa yang semakin meningkat seakan kebutuhan mahasiswa yang sudah ditentukan oleh pagu dari tiap-tiap fakultas maka pengelolaan pelayanan ini membutuhkan transparansi informasi publik, akuntanbilitas serta efisiensi dalam sistem keuangan di Universitas Negeri Sunan Ampel Surabaya.

Tranparansi keuangan dapat diartikan sebagai penyampaian informasi kepada masyarakat luas, dalam rangka pertanggungjawaban dan keputusan kampus terhadap ketentuan dan peraturan yang berlaku dan dapat meningkatkan kefektifitas pengawasan masyarakat dalam terhadap pembangunan serta pelayanan. Dalam UUD nomor 17 tahun 2003 tentang keungan negara maka universitas negeri sunan ampel mengadopsi pilar-pilar utama tata kelola keuangan yang baik yakni dengan memegang prinsip-prinsip transparansi , akuntanbilitas, efisiensi dan kepatuhan terhadap pemerintah.

Pengelolaan sistem informasi dan sistem manajemen yang berbelit-belit menyebabkan sulitnya publik mengakses informasi yang berguna untuk mengawasi setiap kegiatan perguruan tinggi. Salah satu cara agar perguruan tinggi terbebas dari praktek-praktek korupsi adalah dengan memperbaiki tata kelola perguruan tinggi, yaitu dengan menyediakan media informasi yang baik maka dari itu dibagian sistem keuangan Universitas Negeri Sunan Ampel Surabaya juga diperlukan adanya sistem prinsip-prinsip transparansi, akuntanbilitas, dan efisiensi agar semua orang dapat dengan mudah mengetahui informasi tata kelola keuangan serta sistem manajemen yang jelas.

Keterbukaan sistem informasi manajemen publik demi untuk menjamin kebebasan akses informasi terkait tata kelola univeritas masih sangatlah minim, jika ingin mengetahui sistem informasi keuangan harus mempunyai izin dan tujuan tertentu sesuai kebutuhan dan harus melewati berbagai macam proses yang berbelit-belit. Maka 
dari itu pihak univerrsitas harus mampu memberikan ketersediaan informasi serta publikasi yang baik melalui website agar publik dapat dengan mudah mengakses suatu informasi dengan mudah.

Dari berbagai macam permasalahan yang ada sistem pengelolaan data perlu diperbaiki agar terciptanya Perguruan tinggi yang transparan, akuntanbel serta efisien. Bila telah demikian maka kontrol publik terhadap Universitas Negeri Islam Sunan Ampel Surabaya dapat terhindar dari praktik korupsi, serta pihak universitas akanlebih berhati-hati dalam mengelola sistem informasi. Dengan begini UINSA akan menjadi model pengelolaan keterbukaan informasi publik yang baik serta mampu menciptakan kau intelektual yang menjadi contoh yang baik dalam pelelolaan sistem informasi dengann menganut prinsip-prinsip transparansi, akuntabilitas serta efisiensi yang baik. Dalam tulisan inilah akan dibahas bagaimana prinsip akuntabilitas, transparansi, dan efisiensi keuangan di universitas khususnya di UIN Sunan Ampel.

\section{Rumusan Masalah}

1. Bagaimana penerapan manajemen keuangan UIN Sunan Ampel berdasarkan Tata Kelola Transparansi Informasi Publik, Akuntabilitas, dan Efisiensi Keuangan di Universitas?

2. Bagaimana Kendala penerapan manajemen keuangan UIN Sunan Ampel berdasarkan Tata Kelola Transparansi Informasi Publik, Akuntabilitas, dan Efisiensi Keuangan di Universitas?

3. Bagaimana solusi yang dapat dilakuan untuk memaksimalkan penerapan manajemen keuangan UIN Sunan Ampel berdasarkan Tata Kelola Transparansi Informasi Publik, Akuntabilitas, dan Efisiensi Keuangan di Universitas?

\section{Tujuan Penulisan}

1. Untuk mengetahui penerapan manajemen keuangan UIN Sunan Ampel berdasarkan Tata Kelola Transparansi Informasi Publik, Akuntabilitas, dan Efisiensi Keuangan di Universitas

2. Untuk Mengetahui dan Menganalisa Kendala penerapan manajemen keuangan UIN Sunan Ampel berdasarkan Tata Kelola Transparansi Informasi Publik, Akuntabilitas, dan Efisiensi Keuangan di Universitas 
3. Untuk Mengetahui dan Menganalisa solusi yang dapat dilakukan untuk memaksimalkan penerapan manajemen keuangan UIN Sunan Ampel berdasarkan Tata Kelola Transparansi Informasi Publik, Akuntabilitas, dan Efisiensi Keuangan di Universitas

\section{Landasan Teori \\ Manajemen Keuangan}

Manajemen keuangan merupakan semua aktifitas organisasi yang berhubungan dengan usaha-usaha mendapatkan dana dan menggunakannya secara efektif dan efisien (Sunarta, 2001).

\section{Trasnparansi Keuangan}

Transparansi memiliki arti jelas dan bersifat terbuka. Istilah transparansi dapat pula diartikan sebagai kejelasan serta keterbukaan mengenai suatu informasi. Transparansi merupakan prinsip yang menjamin akses atau kebebasan setiap orang untuk memperoleh informasi tentang penyelenggaraan pemerintahan, yakni informasi tentang kebijakan, proses pembuatan dan pelaksanaannya, serta hasilhasil yang dicapai (Depdagri, 2002). Transparansi anggaran keuangan adalah keterbukaan informasi mengenai sektor keuangan publik. Transparansi anggaran mengacu pada seberapa jauh publik dapat memperoleh informasi atas aktivitas keuangan suatu organisasi dan implikasinya.

\section{Akuntabilitas Keuangan}

Akuntabilitas publik merupakan kewajiban agen untuk mengelola sumber daya, melaporkan, dan mengungkapkan segala aktivitas dan kegiatan yang berkaitan dengan penggunaan sumber daya publik kepada pemberi mandate (Mahmudi, 2010). Akuntabilitas merupakan asas yang akan menentukan bahwa setiap kegiatan dan hasil akhir dari pengelolan anggaran keuangan yang harus dapat dipertanggungjawabkan. Akuntabilitas dalam konsep good governance berkaitan dengan tanggung jawab atas manajemen perguruan tinggi terhadap pihak pemerintah, sesuai dengan peraturan yang berlaku (Harsono, et all, 2016). 


\section{Efisiensi Keuangan}

Sesuai dengan Pemendagri No.13 tahun 2006, efisiensi merupakan hubungan antara masukan (input) dan keluaran (output), efisiensi merupakan ukuran apakah barang yang dibeli dan digunakan oleh organisasi perangkat pemerintah untuk mencapai tujuan organisasi perangkat pemerintah. Efisiensi erat kaitannya dengan konsep produktivitas. Pengukuran dapat dilakukan dengan menggunakan perbandingan antara output yang dihasilkan terhadap input yang digunakan. Proses kegiatan operasional dapat dikatakan efisien apabila suatu hasil kerja dapat dicapai dengan penggunaan sumber daya dan dana yang serendah-rendahnya (Yunianti, 2015).

\section{Sistem Informasi Keuangan}

Sistem Informasi Keuangan adalah sistem informasi yang memberikan informasi kepada orang atau kelompok baik di dalam perusahaan maupun di luar perusahaan mengenai masalah keuangan. Dan Menyediakan informasi mengenai arus uang bagi para pemakai diseluruh perusahaan. Dalam hal ini adalah uang dibahas adalah sistem informasi yang berada di Universitas.

\section{Metode Penelitian Jenis Penelitian}

Jenis penelitian ini menggunakan metode kualitatif dengan pengambilan data wawancara yang bertujuan untuk mengambil sampel dari bidang keuangan Universitas dengan melakukan kegiatan penelitian yang dilakukan untuk mendapatkan suatu kepastian informasi pada Tata Kelola Transparansi Informasi Publik, Akuntabilitas, dan Efisiensi Keuangan di Universitas yang meliputi persiapan survei dan wawancara, wawancara di bidang keuangan Rektorat UIN Sunan Ampel, pengolahan data dan evaluasi. Hasil penerapan penelitian survei ini untuk mendapatkan kebenaran tentang suatu masalah Tata Kelola Transparansi Informasi Publik, Akuntabilitas, dan Efisiensi Keuangan di Universitas serta akan memaparkan data dari objek penelitian, dan menginterpretasikan dan menganalisisnya secara sistematis.

\section{Sumber Data}

Penelitian ini membutuhkan dua jenis sumber data, yaitu sebagai berikut: 


\section{Data Primer}

Data jenis ini diperoleh secara langsung di lapangan berupa katakata atau tindakan yang diperoleh melalui wawancara mendalam (indeepth interview) untuk itu dibangun hubungan wawancara yang terstruktur dengan memberikan pertanyaan yang menunjukkan keingintahuan, kerjasama yang pada akhirnya informan berpartisipasi untuk memberikan informasi yang valid. Adapun metode yang kita ambil adalah menggunakan model Key person.

2. Data Sekunder

Data sekunder adalah data yang diperoleh dari bahan kepustakaan berupa buku dan jurnal. Data Sekunder kami gunakan sebagai bahan bacaan dan teori awal sebelum pengambilan data dan sebgai bahan analisa data setelah dilaksanakan wawancara.

\section{Metode dan Teknik Pengambilan Data}

Menurut Sugiyono (2013:2) metode penelitian merupakan cara ilmiah untuk mendapatkan data dengan tujuan dan kegunaan tertentu. Pengumpulan data dapat didefinisikan sebagai pengumpulan data dan merupakan langkah yang paling strategis dalam penelitian, karena tujuan utama dari penelitian adalah mendapatkan data (Sugiyono, 2013:224). Metode dan teknik pengumpulan data yang digunakan pada penelitian ini adalah metode pengumpulan data primer yang berupa observasi lapangan (survei), serta mendapatkan informasi yang tepat dari narasumber terpercaya (wawancara).

\section{Analisa Data}

Analisis data dalam penelitian ini menggunakan analisis data kualitatif. Metode kualitatif mencakup prosedur penelitian yang menghasilkan data desktriptif berupa kata-kata tertulis atau dari penjelasan lisan dari orang-orang yang menjadi objek wawancara yang dipadu padankan dengan analisa berdasarkan toeri teori relevan yang ada.

\section{Pembahasan}

Penerapan manajemen keuangan UIN Sunan Ampel berdasarkan Tata Kelola Transparansi Informasi Publik, Akuntabilitas, dan Efisiensi Keuangan di Universitas Dalam manajemen keuangan di dunia pendidikan tentu diperlukan ke hati hatian dan juga kejujuran dengan berprinsip pada akuntabilitas, transparansi dan efisiensi. Berdasar pada 
Undang-undang No. 20 Tahun 2003 Pasal 48 yang menyatakan bahwa pengelolaan dana pendidikan berdasarkan pada prinsip keadilan, efisiensi, transparansi, dan akuntabilitas publik. Berikut merupakan pembahasan dari masing-masing prinsip tersebut :

\section{Transparansi}

Transparan dalam bidang pengelolaan dapat diartikan sebagai adanya keterbukaan dalam mengelola suatu kegiatan. Keterbukaan tersebut dapat meliputi keterbukaan dalam sumber pemasukan dan jumlahnya, rincian penggunaan, dan pertanggung jawabannya harus jelas sehingga dapat memudahkan pihak-pihak yang berkepentingan untuk mengetahuinya. Transparansi keuangan diperlukan dalam rangka meningkatkan tingkat kepercayaan stakeholder, diantaranya orangtua mahasiswa, masyarakat dan pemerintah. Disamping itu transparansi dapat menciptakan kepercayaan timbal balik antara pemerintah, masyarakat, orang tua mahasiswa dan seluruh civitas academica melalui penyediaan informasi dan menjamin kemudahan di dalam memperoleh informasi yang akurat dan memadai.

Transparansi dalam pengelolaan keuangan kampus atau universitas telah menjadi kewajiban kampus secara perundang-undangan. Melalui diberlakukannya Undang-Undang Nomor 14 tahun 2008 tentang Keterbukaan Informasi Publik (UU KIP). Pemerintah bersama DPR memudahkan masyarakat memiliki ruang terbuka untuk memperoleh informasi dari Badan Publik Pemerintah maupun Badan Publik NonPemerintah dalam menjalankan fungsi, tugas dan wewenangnya.

Sesuai dengan UU No. 20 Tahun 2003, universitas merupakan sebuah badan publik penyelenggara negara dalam bidang pendidikan yang mengurusi jenjang pendidikan tinggi. Demikian pula dengan anggaran untuk semua perguruan tinggi/ universitas (negeri maupun swata) dalam pelaksanaannya juga ditopang oleh APBN dan pembayaran biaya pendidikan oleh mahasiswa. Tentunya jika merujuk pada pengertian badan publik dalam UU KIP, universitas merupakan salah satu badan publik yang wajib membuka informasi bagi masyarakat. Dengan kata lain dengan adanya UU KIP ini berlaku per 30 April 2010, maka Universitas wajib menyediakan informasi baik yang bersifat serta merta, berkala, maupun tersedia setiap waktu.

UU KIP sendiri tentang Badan Publik, Pasal 1 ayat (3) "Badan Publik adalah lembaga eksekutif, legislatif, yudikatif, dan badan lain yang fungsi dan tugas pokoknya berkaitan dengan penyelenggaraan negara, yang sebagian atau seluruh dananya bersumber dari Anggaran 
Pendapatan dan Belanja Negara dan/atau Anggaran Pendapatan dan Belanja Daerah, atau organisasi non-pemerintah sepanjang sebagian atau seluruh dananya bersumber dari Anggaran Pendapatan dan Belanja Negara dan/atau Anggaran Pendapatan dan Belanja Daerah, sumbangan masyarakat, dan/atau luar negeri".

Tertulis jelas dalam bunyi pasal di atas mengenai "penyelenggaraan negara". Dalam hal ini Universitas adalah penyelenggara negara dalam bidang pendidikan. Selama ini kita juga mengetahui jika perguruan tinggi swasta adalah sebuah badan publik yang mendapat dana yang bersumber dari APBN (Hibah, beasiswa, bantuan-bantuan lain) dan terutama dari masyarakat (mahasiswa dalam bentuk pembayaran SPP).

Perguruan Tinggi merupakan badan publik diwajibkan membuka diri terhadap semua yang berkaitan dengan pengelolaan yang terkait publik sebagaimana dijelaskan dalam UU No. 14 tahun 2008 tentang Kewajiban Badan Publik ayat (1) "Badan Publik wajib menyediakan, memberikan dan/atau menerbitkan Informasi Publik yang berada di bawah kewenangannya kepada Pemohon Informasi Publik, selain informasi yang dikecualikan sesuai dengan ketentuan" dan ayat (2) "Badan Publik wajib menyediakan Informasi Publik yang akurat, benar, dan tidak menyesatkan". Dengan adanya UU No. 14 tahun 2008 tentang KIP ada harapan dari pihak kampus maupun mahasiswa dapat menjalankan prinsip transparan. Sebuah pengelolaan keuangan yang jujur dan bertanggung jawaban serta siapapun bisa mengakses informasi publik terkait Perguruan Tinggi. PTN dalam pengelolaan keuangannya harus mengikuti sistem pengelolaan keuangan berdasarkan Keputusan Menteri Dalam Negeri No. 29 Tahun 2002 tentang Pedoman Pengurusan, Pertanggungjawaban dan Pengawasan Keuangan Daerah serta Tata Cara Penyusunan Anggaran Pendapatan dan Belanja Daerah, Pelaksanaan Tata Usaha Keuangan Daerah dan Penyusunan Perhitungan Anggaran Pendapatan dan Belanja Daerah.

2. Akuntabilitas

Akuntabilitas di dalam pengelolaan keuangan dapat diartikan penggunaan uang perguruan tinggi dapat dipertanggung jawabkan sesuai dengan perencanaan yang telah ditetapkan sebelumnya. Berdasarkan perencanaan yang telah ditetapkan dan peraturan yang berlaku, maka perguruan tinggi membelanjakan uang secara bertanggung jawab. Pertanggung jawaban dapat dilakukan kepada orang tua, masyarakat dan pemerintah. Ada tiga pilar utama yang menjadi prasyarat terbangunnya akuntabilitas, yaitu :

227 OECONOMICUS Journal of Economics 
1. adanya transparansi para penyelenggara perguruan tinggi dengan menerima masukan dan mengikut sertakan berbagai komponen dalam mengelola perguruan tinggi

2. adanya standar kinerja di setiap institusi yang dapat diukur dalam melaksanakan tugas, fungsi dan wewenangnya

3. adanya partisipasi untuk saling menciptakan suasana kondusif dalam menciptakan pelayanan masyarakat dengan prosedur yang mudah, biaya yang murah dan pelayanan yang cepat.

4. Efektivitas

Efektif seringkali diartikan sebagai pencapaian tujuan yang telah ditetapkan. Efektivitas lebih menekankan pada kualitatif outcomes. Pengelolaan keuangan dapat dikatakan memenuhi prinsip efektivitas apabila kegiatan yang dilakukan dapat membiayai aktivitas-aktivitas yang sudah direncanakan guna mencapai tujuan lembaga yang telah ditetapkan.

5. Efisiensi

Efisiensi erat kaitannya dengan kuantitas hasil suatu kegiatan. Efisiensi adalah perbandingan yang terbaik antara masukan (input) dan keluaran (output) atau antara daya dan hasil. Daya yang dimaksud meliputi tenaga, pikiran, waktu, biaya. Perbandingan tersebut dapat dilihat dari dua hal yaitu Dilihat dari segi penggunaan waktu, tenaga dan biaya. Kegiatan dapat dinyatakan bila penggunaan waktu, tenaga dan biaya tertentu dapat mencapai hasil yang maksimal. Dan dilihat dari segi hasil. Kegiatan dapat dinyatakan bila dengan penggunaan waktu, tenaga dan biaya tertentu memberikan hasil sebanyak-banyaknya baik kuantitas maupun kualitasnya.

Dengan tingginya tingkat efisiensi dan efektivitas memungkinkan terselenggaranya pelayanan terhadap masyarakat menjadi lebih memuaskan dengan menggunakan sumber daya yang tersedia secara optimal dan bertanggung jawab. Penerapan Manajemen Keuangan di UIN Sunan Ampel berdasarkan prinsip Akuntabilitas, Trasnparansi, dan Efisiensi

Terkait dengan keterbukaan dan efisiensi keuangan berdasarkan hasil wawancara dengan narasumber, pada bagian keuangan UIN Sunan Ampel Surabaya, terkait pada anggaran seluruhnya bagian 
perencanaan, dan mengenai anggaran untuk memberikan semua telah diketahui mulai dari telah diketahui mulai dari akses ke semua fakultas telah diketahui dengan pasti jumlah pagu yang dibutuhkan untuk menghasilkan suatu output. Oleh karena itu, anggaran sudah diketahui dan dirinci serta dapat dipertanggungjawabkan. Terkait pendanaan mahasiswa seperti BEM, apabila akan menyelenggarakan suatu kegiatan diharuskan membuat proposal dan disposisi pimpinan yang memuat perincian dalam penentukan jumlah anggaran dan penggunaan anggaran yang yang dapat dipertanggungjawabkan, apabila proposal telah lengkap maka pendanaan akan cair.

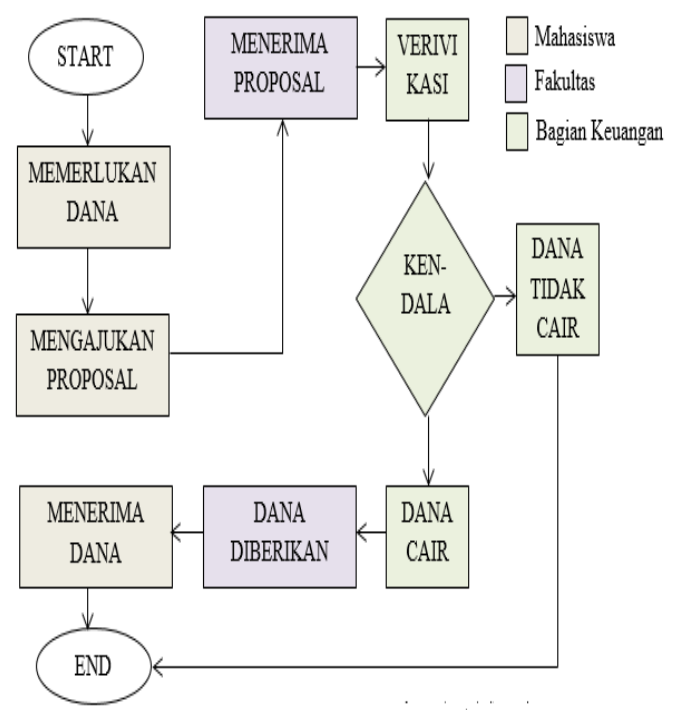

Gambar 1. Diagram Proses Pengajuan dana Mahasiswa

Namun pada prinsipya, proses pencairan anggaran di bagian keuangan UIN Sunan Ampel Surabaya tidak dapat secara langsung cair. Dalam hal tertentu, ada yang diberi DP dulu, dan dana dapat pula diberikan diakhir, tergantung pada urgensi kegiatan yang dilakukan.

Kemudian untuk akuntanbilitas di bagian keuangan UIN Sunan Ampel Surabaya telah mengikuti aturan pemerintah. Dalam hal ini, telah sesuai dengan peraturan pemerintah keuangan dan proses pendanaan mengacu pada tersebut, serta tidak boleh melebihi batas yang telah ditentukan. Apabila melebihi standart biaya masukan maka tidak akan dibayar sama sekali (harus mengacu pada pemerintah keuangan).

229 OECONOMICUS Journal of Economics 
Kendala penerapan manajemen keuangan UIN Sunan Ampel berdasarkan Tata Kelola Transparansi Informasi Publik, Akuntabilitas, dan Efisiensi Keuangan di Universitas

\section{Gambar 2. Data Flow Diagram dalam manajemen keuangan di UIN Sunan Ampel}

Kendalanya yang terjadi yaitu terkait dalam aplikasi sistem yang parsial karena berjalan sendirisendiri. Dalam APBN, yang mencakup dalam akuntansi menjadi satu, kalau kerjanya SPJ dia sendiri-sendiri. Jadi, mekanisme pertanggung jawabannya sedikit berbeda, yang BLU di UIN Sunan Ampel Surabaya yang APBN harus keluar di KPPN di JQ kemenkeu , kadangkala terdapat proses yang sangat lama dikarenakan terdapat kendala yang kadang tidak sesuai, maka dikembalikan ke bagian keuangan. Contohnya, pemantauan kendala langsung

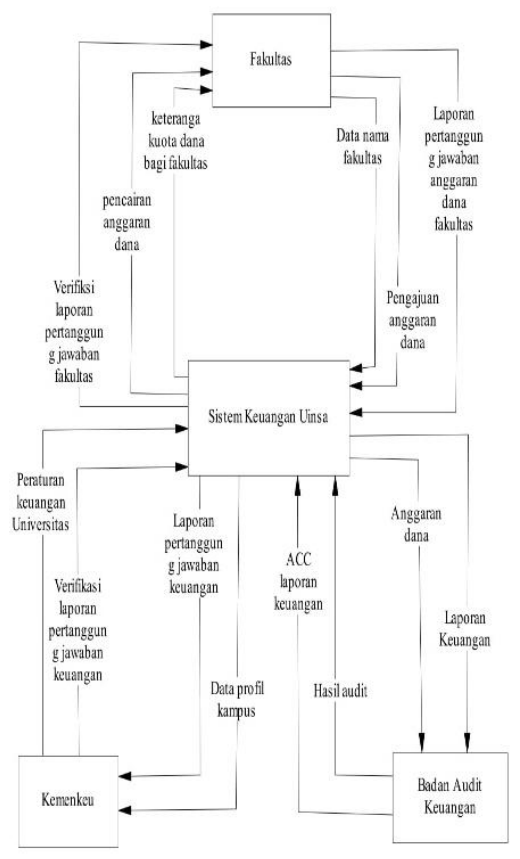
yang pernah dialami oleh narasumber yaitu agak susahnya pengendalian pagu dikarenakan jumlahnya yang tidak sedikit dan kegiatannya yang juga tidak sedikit. Apabila dalam mengendalikan rinci jika tidak menggunakan apk agak kesulitan. Hal tersebut dikarenakan apabila pengendalikan dilakukan secara manual maka pengendaliannya akan menjadi lebih rumit dan harus dilakukan dengan sangat hati-hati, saat proses control di bagian bendahara, kabag dan bagian verfikator, kadang kala tidak match. kadang terjadi pula leg pada proses alur yang berputar-putar tadi. Apabila menggunakan aplikasi, maka akan sesuai dengan prinsipnya yaitu apabila di hulu A maka dihilir juga A. Sehingga dapat sejalan. 
Solusi penerapan manajemen keuangan UIN Sunan Ampel berdasarkan Tata Kelola Transparansi Informasi Publik, Akuntabilitas, dan Efisiensi Keuangan di Universitas

Solusi yang dilakukan untuk sementara ini yaitu memaksimalkan sedemikian rupa sendiri menggunakan excel dan bagian keuangan akan melakukan kroscek secara bersama-sama, serta lebih mengintensifkan penggunaan kendali-kendali yang ada di bagian keuangan itu sendiri.

Terkait dengan peraturan keuangan yang ada di UIN Sunan Ampel berdasarkan tuturan dari narasumber, sudah terdapat peraturan-peraturan keterbukaan, beberapa diantaranya yaitu mengikuti PPID semua informasi tersedia yang ditunjuk untuk itu, untuk bagian humas dan rektor pun memiliki informasi yang jelas. Jika mahasiswa ingin mengetahui informasi tentang informasi suatu hal, bagian keuangan pasti memberitahukan informasi tersebut tetapi dengan syarat adanya izin yang jelas dan dengan tujuan yang jelas pula. Dalam hal Pengawasan pada setiap tahunnya, telah ada pemeriksaan dari internal kampus yaitu SIP, sedangkan irjen dari kementrian adalah auditor, dan terdapat pula BPK dari pihak luar, disertai pihak yang lebih independen yaitu KAP. Beberapa tahun yang lalu terdapat pula pemeriksaan yang dilakukan oleh KPK. Hal tersebut menunjukkan bahwa pemeriksaan anggaran di bagian keuangan UIN Sunan Ampel Surabaya bukan hanya berasal dari pihak internal saja. Kadang itu ada level" tertentu yang memang harus seperti itu bukannya tidak terbuka dan tertutup untuk memberi informasi.

Laporan anggaran yang ada di UIN Sunan Ampel telah memenuhi standar yang berlaku, terdapat 2 sumber yaitu BLU dan APBN. Kedua sumber tersebut hanya berbeda dimekanismenya, apbn dikemenkeu dan BLU di UIN Sunan Ampel sendiri, dan proses pelaporan ini ada triwulanan, pengesahan, semester, dan tahunan. Dokumen-dokumen tersebut harus dispjkan setiap bulannya. Bendahara akan mempertanggungjawakan tiap bulan dan dari situ akan dijadikan triwulanan semesteran, tahunan dan semua harus singkron. Kaidah urutan birokasi harus benar, sistem yang dijalankan juga harus benar.

231 OECONOMICUS Journal of Economics 
Dalam hal wewenang kampus dalam manajemen keuangan, menurut narasumber di UIN Sunan Ampel Surabaya tidak ada wewenang atau otoritas kampus, dikarenakan kampus telah diatur dalam lingkup-lingkup peraturan kemenkeu, auditor-auditor irjen, dan kemenag. Semua badan tersebut mempunyai standart yang harus diikuti yang telah tertuang jelas. Sebagai contoh yaitu SPM, dalam hal tertentu diluar lingkup peraturan yang tidak melebihi peraturan diatasnya kita bisa menentukan sendiri dan tidak bertentangan. Dalam sisi akuntanbilitas dan efesiensi untuk penyatuan standart biaya, apabila dikampus hanya diberikan seberapa persen itu termasuk dalam keefisienan dalam prinsipnya. contohnya dalam stadium general kebutuhan di spm maksimal 900 dan tidak boleh lebih dari itu.

\section{Penutup \\ Kesimpulan}

Menciptakan pengelolaan keuangan yang menganut prinsip transparansi, akuntabilitas, dan efisiensi keuangan merupakan tujuan dari setiap universitas. UIN Sunan Ampel Surabaya telah berupaya mamaksimalkan penerapan prinsipprinsip tersebut dalam proses manajemen keuangan. Transparansi anggaran yang diterapkan diantaranya berupa pemberian semua akses ke semua fakultas terkait informasi pagu yang dibutuhkan untuk menghasilkan suatu output. Prinsip Akuntabilitas di bagian keuangan UIN Sunan Ampel Surabaya juga telah mengikuti aturan pemerintah, dimana pelaksanaannya telah sesuai dengan peraturan pemerintah keuangan dan proses pendanaan mengacu pada peraturan tersebut. Sedangkan pelaksanaan prinsip efisiensi keuangan adalah dengan pencairan dana yang sesuai dengan standar yang telah ditetapkan.

Pengelolaan keuangan dalam universitas tidak dapat terlepas dari kendala-kendala yang dapat menghambat lancarnya proses pengelolaan keuangan. Pembuatan laporan dan manajemen anggaran dengan menggunakan aplikasi sistem yang parsial antara pelaporan APBN dan BLU, dan eror serta lag sistem yang kerapkali terjadi merupakan kendala yang terdapat dalam pelaksanaan pengelolaan keuangan UIN Sunan Ampel Surabaya. Pengendalian pagu dan kegiatan-kegiatannya yang tidak sedikit 
jumlahnya juga menyebabkan proses pengendalian menjadi lebih lama. Dari kesemuanya proses keuangan yang ada dengan mengutamakan prinsip akuntabilitas, efisiensi dan transparansi tentunya adalah demi mewujudkan suatu tatanan Good University Government di dalam universitas khususnya UIN Sunan Ampel.

\section{Saran}

Solusi-solusi yang dapat dilakukan oleh bagian keuangan yaitu dengan memaksimalkan penggunaan excel sebagai sarana rekapitulasi sementara. Hal tersebut didukung pula dengan pengecekan yang dilakukan secara bersama-sama dan lebih mengintensifkan penggunaan kendali-kendali yang ada di bagian keuangan itu sendiri.

\section{Daftar Pustaka}

Ariani, Dewi. Pengelolaan Keuangan Perguruan Tinggi di Indonesia. FKIP Universitas Mahaputra Muhammad Yamin.

Badan Perencanaan Pembangunan Nasional \& Departemen Dalam Negeri. 2002. Buku Pedoman Penguatan Pengamanan Program Pembangunan Daerah.

Harsono, Arina Hidayati. 2016. Penerapan Tata Kelola Keuangan di Universitas Islam Batik Surakarta untuk Mewujudkan Good University Governance, Jurnal Pendidikan Ilmu Sosial, Vol.26 No.2.

Mahmudi. 2010. Manajemen Kinerja Sektor Publik, Edisi Kedua. Yogyakarta: UPP STIM YKPN.

Sunarta. 2001. Manajemen Keuangan (Teori, Konsep, dan Aplikasi), Universitas Negeri Yogyakarta.

Yunianti, Umi. 2015. Analisa Efisiensi dan Efektivitas Anggaran Pendapatan dan Belanja Desa (APBDesa), Seminar Nasional Universitas PGRI Yogyakarta. Yogyakarta. 